\title{
Sustained reduction of proteinuria in Type 2 (non-insulin-dependent) diabetes following diet-induced reduction of hyperglycaemia
}

\author{
B. Vasquez, E.V.Flock, P.J.Savage*, M. Nagulesparan, L.J. Bennion, H. R. Baird and P. H. Bennett \\ Phoenix Clinical Research Section and Epidemiology and Field Studies Branch, National Institute of Arthritis, Diabetes, \\ Digestive and Kidney Diseases, National Institutes of Health, Phoenix, Arizona, USA
}

\begin{abstract}
Summary. To determine whether sustained control of hyperglycaemia in Type 2 (non-insulin-dependent) diabetic patients would diminish proteinuria, the effect of hypocaloric diet therapy (500 kcal/day) on proteinuria was assessed in obese, Type 2 diabetic patients $(n=24)$ and compared with results obtained for obese subjects with normal glucose tolerance $(n=7)$ and impaired glucose tolerance $(n=6)$. Diet therapy of similar mean duration resulted in similar percentage weight loss (mean percentage of original weight \pm SEM) in diabetic $(13.6 \pm 1.6 \%)$, glucose intolerant $(16.4 \pm 3.3 \%)$ and obese nondiabetic $(11.0 \pm 1.0 \%)$ subjects. Following therapy, plasma glucose concentrations $2 \mathrm{~h}$ after an oral glucose load declined in the diabetic $(18.34 \pm 0.81$ to $10.67 \pm 0.50 \mathrm{mmol} / 1$, mean \pm SEM; $p<0.001)$ and in the glucose intolerant subjects $(10.2 \pm 0.3$ to $7.3 \pm 0.4 \mathrm{mmol} / 1, p<0.01)$ while remaining unchanged in the obese non-diabetic subjects $(7.09 \pm 0.23$ to $6.77 \pm 0.32 \mathrm{mmol} / 1$, NS). Concentrations of total protein of plasma origin and albumin in 24-h urine collections were quantified by a sensitive immunonephelometric assay using specific antisera. Initially, 24-h excretion of total protein and albumin were elevated in the diabetic [mg protein $/ 24 \mathrm{~h}$; (median $\pm 95 \%$ confidence limits): 63 (42-138), $p<0.05$ albumin: $26(14-56), p<0.05]$ and glucose intolerant subjects
\end{abstract}

[protein : 52 (13-92), NS; albumin: 24 (3-61), NS] compared with the non-diabetic subjects [protein: 20 (5-38); albumin: $6.2(3.5-9.5)]$. Following diet therapy, both total protein and albumin excretion were reduced significantly in diabetic subjects $(p<0.001)$ and similar decreases were observed in clearance rates of protein and albumin. Initially, 11 out of the 24 diabetic subjects had 24-h albumin excretion in the subclinical range $(>30,<500 \mathrm{mg} / 24 \mathrm{~h}$ ), whereas following diet therapy, only three out of the 11 had subclinical albuminuria. For all subjects, the decrease in albumin excretion following diet therapy was significantly correlated with the initial albumin excretion $(r=0.63, p<0.0001)$. In one diabetic subject, whose glucose tolerance and albumin excretion were sequentially monitored for 14 months, the decreases in glycaemia and proteinuria observed in the first month of therapy persisted after discontinuation of diet therapy. Thus, metabolic control of Type 2 diabetes by a hypocaloric diet produced significant sustained reductions in proteinuria. The question remains whether or not this retards the development of clinical nephropathy or end stage renal disease.

Key words: Type 2 diabetes, microvascular complications, proteinuria, albuminuria, hypocaloric diet.
Throughout the last decade, evidence has accumulated to suggest that control of hyperglycaemia in man and animals may reverse or diminish the rate of progression of the microvascular complications of diabetes [1-3]. Definitive proof of this relationship has not been established. Major reasons for this failure may be that conventional methods of diabetic control do not achieve sustained normalization of hyperglycaemia [4-6], and that many years of observation are necessary

* Present address: Department of Internal Medicine, Wayne State University School of Medicine, Veterans Administration Medical Center, Allen Park, MI 48101, USA. to document the natural history of microvascular complications in man by conventional measurements [7-9]. Recently, subclinical increases in urinary albumin excretion in subjects with Type 1 (insulin-dependent) diabetes have been reported to predict the development of clinical diabetic nephropathy [10] and such changes have been claimed to be reversible $[11,12]$. The combination of an increase in knowledge of how to achieve sustained control of hyperglycaemia in Type 2 (noninsulin-dependent) diabetes mellitus $[13,14]$ and improvements in the sensitivity of methods to measure changes in urinary protein concentration $[15,16]$ have made it possible to examine the effects of metabolic 
control over a period of several months in subjects with a spectrum of glucose intolerance and minimal to moderate increases in urine protein excretion. The aim of this study was to determine whether elevated urinary protein excretion in obese Type 2 diabetic subjects can be reduced by hypocaloric diet therapy.

\section{Subjects and methods}

\section{Patient selection}

Patients were selected to provide a spectrum of glucose tolerance. Their characteristics are shown in Table 1 . All were admitted to a metabolic research ward and gave written consent for subsequent studies. Except for obesity and/or diabetes, all were in good health as judged by history, physical examination and laboratory studies including a full blood count, electrocardiogram, total serum protein, albumin, alkaline phosphatase, serum glutamic-oxaloacetic transaminase, bilirubin, thyroxine and $08: 00 \mathrm{~h}$ plasma cortisol. Evidence that none of the subjects had urinary tract infections was provided by normal results of urinalysis, which included microscopic estimation of white blood cells and bacterial contamination. All had normal serum creatinine concentrations $(<15 \mu \mathrm{mol} / \mathrm{l})$ and no history of other renal disease. Subjects were not taking medications at the time of the studies. Initial blood pressure measurements were obtained on the day of admission.

The results of a 100-g oral glucose tolerance test were used to classify the subjects as (1) non-diabetic subjects having normal glucose tolerance (fasting plasma glucose concentrations $<6.4 \mathrm{mmol} / 1$ and 2-h plasma glucose concentrations $<7.8 \mathrm{mmol} / 1, n=7$ ); (2) subjects with impaired glucose tolerance having normal fasting glucose but elevated post-challenge glucose concentrations (fasting plasma glucose $<6.4 \mathrm{mmol} / 1, \geqslant 7.8 \mathrm{mmol} / 1$ and plasma glucose $<11.1 \mathrm{mmol} / 1$, $n=6$ ); and (3) diabetic patients (fasting plasma glucose $>7.8 \mathrm{mmol} / 1$ and/or 2 -h plasma glucose $>11.1 \mathrm{mmol} / \mathrm{l}, n=24)$. Duration of known diabetes ranged from newly diagnosed to 16 years.

\section{Study design}

Subjects were placed on a weight maintaining, 300-g carbohydrate diet until the initial studies were completed. After 3 days on this diet, each patient received a 100-g oral glucose load (Koladex, Custom Laboratories, Baltimore, Maryland, USA) with determination of glucose concentrations at $-30,0,30,60,120$, and $180 \mathrm{~min}$. On a subsequent day, a blood sample was obtained for measurement of creatinine, albumin and total protein concentrations, and urine was collected for a 24-h period for determination of creatinine, protein and albumin concentrations.

Each subject then began a $500 \mathrm{kcal}, 50$-g carbohydrate diet which was continued for at least 4 weeks. During this period each subject was given $325 \mathrm{mg}$ of ferrous sulphate and vitamin supplements daily and potassium chloride as needed to prevent hypokalaemia. Fasting plasma glucose concentrations were determined weekly. At the end of therapy, subjects were fed a $1500 \mathrm{kcal}, 300-\mathrm{g}$ carbohydrate diet for 3 days and the oral glucose tolerance test was repeated. On the subsequent day, while still on this diet, a 24 -h urine collection was repeated. Details of changes in glucose and glucoregulatory hormone concentrations observed in several of these patients have been described previously [13].

Sequential changes in glucose tolerance and albumin excretion were monitored in one diabetic subject. The hypocaloric diet therapy (6 months) was interrupted several times for retesting after refeeding, as described above. After discontinuation of hypocaloric diet therapy and discharge from the metabolic ward, this subject was then retested 8 months later, at which time glucose tolerance was normal but $14 \mathrm{~kg}$ of weight had been regained. Changes in glucose tolerance and hormone levels in this patient have been described previously [17].

\section{Sample collection}

Blood samples for glucose determinations were collected in tubes containing $30 \mathrm{mg}$ of sodium fluoride, plasma was separated, frozen and subsequently analyzed by the ferricyanide method (Technicon Auto-Analyzer Method File N2b., Technicon Instruments, Tarrytown, New York). Plasma samples were obtained on the day of the 24-h urine collections for measurement of total protein, albumin and creatinine concentrations. During the $24-\mathrm{h}$ collection urine was refrigerated at $4^{\circ} \mathrm{C}$. After addition of sodium merthiolate $(0.1 \%)$ an aliquot of the urine was stored at $-20^{\circ} \mathrm{C}$. Urine was thawed, mixed and centrifuged at $600 \mathrm{xg}$ for $10 \mathrm{~min}$ at $24^{\circ} \mathrm{C}$ before urine assays were performed. Serum and urine creatinine concentrations were measured on the autoanalyzer using a modification of the Folin and $\mathrm{Wu}$ procedure (Technicon Auto-Analyzer Method File N116).

\section{Immunonephelometric assay of total plasma protein and albumin}

An immunonephelometric method was used to measure total protein of plasma origin in urine by reaction with goat antiserum to whole human serum (Meloy Laboratories, Springfield, Vermont). This method, a modification of that previously described [16], measures only proteins of plasma origin, excluding proteins originating from the urinary tract. Buffers used were phosphate buffered saline (PBS, $0.05 \mathrm{~mol} / 1$, $\mathrm{pH} 7.4$ ) and PEG (4\% polyethlene glycol 6000 in PBS). The antiserum to whole human serum was used at a final dilution of $1 / 100$ in PEG. PBS and the diluted antiserum were filtered through polycarbonate membranes (average pore diameter, $0.4 \mu \mathrm{m}$, Nucleopore Corporation, Pleasanton, California). Standards were prepared for total protein from dilutions (2.5-80 mg/1) of Q-pak reference serum (Hyland Diagnostics, Bannockburn, Illinois). The percentage relative light scattering was measured for blanks (no antisera), standards and samples in a nephelometer (Laser Nephelometer PDQ, Hyland Diagnostics) exactly $20 \mathrm{~min}$ after addition of antisera. The concentration of total protein in the sample was obtained by comparing the net percentage relative light scattering of the unknowns (sample minus blank) to the curvilinear standard curve (percentage relative light scattering versus concentrations of standards) using a program provided by Hyland Diagnostics for a TI-59 calculator (Texas Instruments, Austin, Texas).

The concentration of albumin in urine was measured in a similar manner using antiserum to human albumin (Atlantic Antibodies, Westbrook, Maine) at a final dilution of $1 / 250$ and standards (1.5-50 $\mathrm{mg} / 1)$ prepared from Calibrator 4 Serum (Atlantic Antibodies). Urine was assayed either undiluted or, at high levels of proteinuria, after two-to tenfold dilution and plasma samples were diluted 1000 -fold before assay. Clearance rates for total plasma protein, albumin and creatinine were calculated.

Replicate analyses of a urine pool for total plasma protein resulted in an intrassay coefficient of variation of $4.4 \%$ (mean $\pm S D$, $36.4 \pm 1.6 \mathrm{mg} / 1, n=20$ ). A similar assay for albumin of a different pool resulted in a coefficient of variation of $5.6 \%$ (mean $\pm \mathrm{SD}=$ $21.4 \pm 1.2 \mathrm{mg} / \mathrm{l}, n=20$ ). Interassay coefficients of variation were $4.4 \%$ and $6.4 \%$ for total protein (three assays, mean $\pm \mathrm{SD}=68.4 \pm 3.0$ $\mathrm{mg} / \mathrm{l}$ ) and albumin (five assays, mean $\pm \mathrm{SD}=48.1 \pm 3.1 \mathrm{mg} / \mathrm{l}$ ), respectively.

In order to assess stability of an individual's $24-\mathrm{h}$ urinary protein excretion over time without weight loss, multiple 24-h urine collections were obtained from two subjects while on a weight-maintaining diet. The individual coefficients of variation in daily urinary protein excretion for the two subjects were total protein: $10 \%, 9 \%$ and albumin: $14 \%, 9 \%$ for nine collections in 31 days and six collections in 16 days, respectively.

\section{Statistical analyses}

Differences in age, body mass index and duration of diet therapy between groups were compared by Student's t-test and changes in body weight, blood pressure and plasma glucose concentrations within the groups following therapy were determined by the paired t-test. $\mathrm{Be}$ - 
cause of the wide variability of urine protein excretion and clearance, comparisons of changes within each group between the initial and $\mathrm{fi}^{-}$ nal series of tests were made using Fisher's sign test; comparisons between the three groups of subjects at both initial and final testing were made using the Kruskal-Wallis test [18]. For the regression analyses, logarithms of the variables were used and the changes in variables following therapy were expressed as $\ln \left(\mathrm{X}_{1} / \mathrm{X}_{2}\right)$ where $\mathrm{X}_{1}$ and $\mathrm{X}_{2}$ were determined before and after diet therapy, respectively.

\section{Results}

\section{Weight loss and changes in glucose tolerance and blood pressure}

Initially, the non-diabetic subjects and diabetic subjects were equally obese, as measured by body mass index, whereas the subjects with impaired glucose tolerance were slightly more obese (Table 1). Hypocaloric diet therapy of similar mean duration resulted in significant weight loss in all three groups (Table 2). The magnitudes of the weight loss for the groups were not significantly different when expressed either as absolute loss (nondiabetic subjects: $11.6 \pm 2.0 \mathrm{~kg}$; glucose intolerant subjects: $24.1 \pm 6.9 \mathrm{~kg}$; diabetic patients: $15.2 \pm 2.5 \mathrm{~kg}$ ) or as percentage of initial weight (non-diabetic subjects: $11.0 \pm 1.0 \%$; glucose intolerant subjects: $16.4 \pm 3.3 \%$; diabetic patients: $13.6 \pm 1.6 \%$ ).

Table 1. Characteristics of subjects studied

\begin{tabular}{llll}
\hline & $\begin{array}{l}\text { Non-diabetic } \\
\text { subjects } \\
(n=7)\end{array}$ & $\begin{array}{l}\text { Glucose } \\
\text { intolerant } \\
\text { subjects } \\
(n=6)\end{array}$ & $\begin{array}{l}\text { Diabetic } \\
\text { patients } \\
(n=24)\end{array}$ \\
\hline Age (years) & $31.4 \pm 2.6$ & $31.4 \pm 2.5$ & $38.4 \pm 2.1^{\mathrm{b}}$ \\
$\begin{array}{l}\text { Sex (M/F) } \\
\begin{array}{l}\text { Initial body mass } \\
\text { index } \\
\left(\mathrm{kg} / \mathrm{m}^{2}\right)\end{array}\end{array}$ & $4 / 3$ & $4 / 2$ & $17 / 7$ \\
$\begin{array}{l}\text { Duration of therapy } \\
\text { (days) }\end{array}$ & $84 \pm 3.2$ & $47.6 \pm 4.8^{\mathrm{a}}$ & $39.1 \pm 1.7$ \\
\hline
\end{tabular}

Data presented as mean \pm SEM. Significance of difference from control group; ${ }^{\mathrm{a}} p<0.05 ;{ }^{\mathrm{b}} p<0.001$
Before therapy, plasma glucose levels in the diabetic subjects, both fasting and $2 \mathrm{~h}$ after an oral glucose load, were markedly elevated when compared with non-diabetic subjects (Table 2). Following caloric restriction, both fasting and post-challenge glucose levels of the diabetic subjects improved significantly $(p<0.001)$. The improvement in glucose tolerance varied considerably among the diabetic patients, but resulted in reduction of fasting plasma glucose concentrations to within the normal range $(<6.4 \mathrm{mmol} / 1)$ for 21 of the 24 subjects. The 2-h glucose concentration of the diabetic patients remained within the diabetic range for nine subjects, decreased to the impaired range for 14 and became completely normal in one subject. Fasting plasma glucose levels of the glucose intolerant subjects were initially in the normal range, but the 2-h glucose levels were abnormal. After hypocaloric diet therapy and subsequent weight loss, fasting $(p<0.05)$ and 2 -h plasma glucose $(p<0.01)$ concentrations decreased, with four of the six subjects attaining 2-h glucose levels in the normal range. The non-diabetic subjects had normal fasting and postchallenge glucose concentrations on both the initial and final oral glucose tolerance tests.

Significant, but relatively modest, reductions in blood pressure concomitant with weight loss were observed in the diabetic subjects (Table 2). For all subjects, the change in systolic blood pressure was significantly correlated with the change in body weight $(r=0.45$, $p<0.008, n=34$ ). Neither the initial systolic nor diastolic blood pressures correlated significantly with initial urinary protein excretion.

\section{Urinary protein and albumin excretion}

Median 24-h urinary excretion of total protein of plasma origin (Fig. 1 A) was greatest in the diabetic subjects $(p<0.05)$, intermediate in the glucose intolerant subjects and lowest in the non-diabetic subjects on the initial test. Initial fasting plasma glucose concentrations were correlated with the initial $24-\mathrm{h}$ urine protein $(n=37, r=0.42, p<0.05)$ and albumin $(r=0.33, p<$ 0.05 ) excretion. After the period of weight reduction, median protein excretion did not change significantly

Table 2. Effect of diet therapy on body weight, blood pressure and oral glucose tolerance

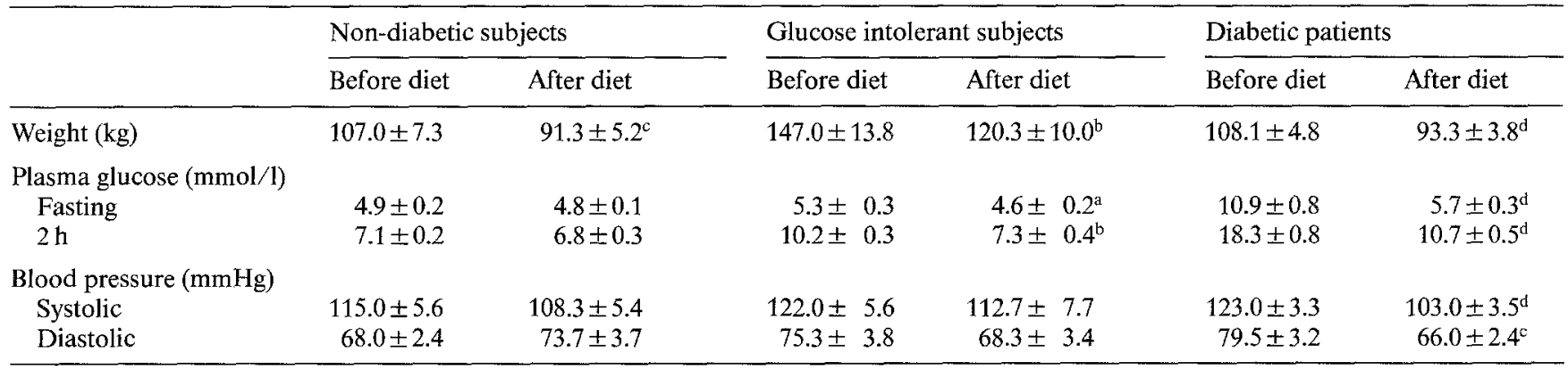

Results expressed as mean \pm SEM. Significance of the changes from before to after diet therapy in each group: ${ }^{\mathrm{a}} p<0.05,{ }^{\mathrm{b}} p<0.01,{ }^{\mathrm{c}} p<0.005$, ${ }^{\mathrm{d}} p<0.001$ 


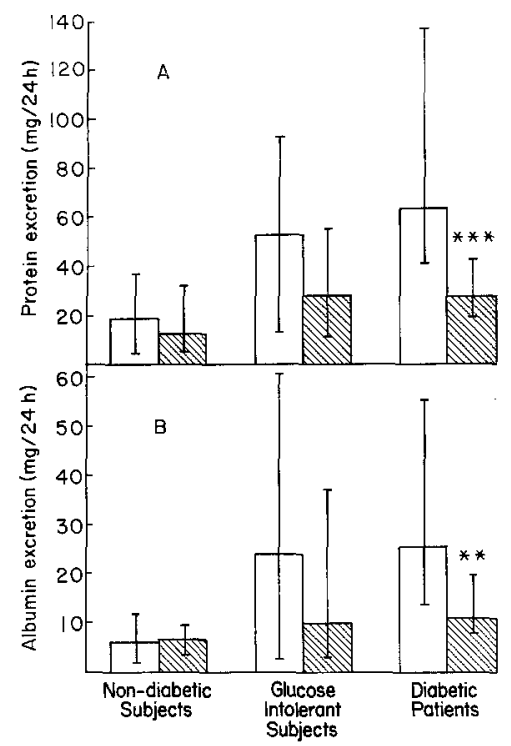

Fig. 1. Urinary protein and albumin excretion. Twenty-four hour urinary excretion (median $+95 \%$ confidence limits) of total protein of plasma origin (A) and albumin (B) in non-diabetic $(n=7)$, glucose intolerant $(n=6)$, and diabetic $(n=24)$ subjects before (open bars) and after (hatched bars) hypocaloric diet therapy. $* * p<0.01$, *** $p<$ 0.001

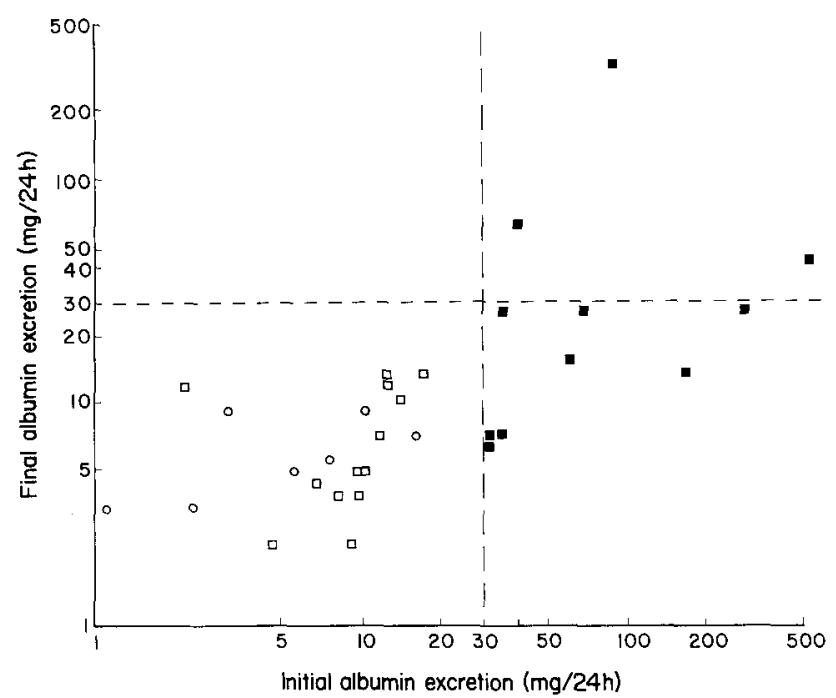

Fig. 2. Individual changes in albumin excretion. Initial 24-h urinary excretion of albumin plotted against albumin excretion following weight loss for non-diabetic subjects $(O)$ and for diabetic subjects who initially had subclinical albuminuria $(>30 \mathrm{mg} / 24 \mathrm{~h}, \boldsymbol{\square})$ or albuminuria in the normal range $(<30 \mathrm{mg} / 24 \mathrm{~h}, \square)$

from initial values in the non-diabetic or impaired glucose tolerant groups but a significant reduction was observed in the diabetic group $(p<0.001)$. Similarly, albumin excretion (Fig. 1B) did not decrease significantly in the non-diabetic and impaired glucose tolerant subjects but declined significantly in the diabetic subjects $(p<0.01)$. The relationship between albumin and protein excretion determined for the final 24-h urine collection for each subject was examined by linear regression analysis. Albumin and protein excretion were linearly related ( $r=0.78, p<0.0001)$ according to the equation: 24 - $\mathrm{h}$ albumin excretion $=0.47 \times 24$ - $\mathrm{h}$ protein excretion -0.7 .

Although the initial 24-h urinary excretion of protein and albumin was highest for the diabetic group, levels in many of the diabetic subjects were within the range found in the non-diabetic subjects (albumin excretion $<30 \mathrm{mg} / 24 \mathrm{~h}$; protein excretion $<60 \mathrm{mg} / 24 \mathrm{~h}$ ). As this upper limit of normal for albumin was similar to the value used by Viberti et al. [10] to discriminate between normoalbuminuria and microalbuminuria and is also similar to the upper limit of normal (1.6-34.2 $\mathrm{mg} / 24 \mathrm{~h}, 95 \%$ confidence limits) previously observed for 239 apparently healthy subjects using a nephelometric assay for albumin [19], these levels of excretion of albumin or protein (albumin $>30 \mathrm{mg} / 24 \mathrm{~h}$; protein $>60$ $\mathrm{mg} / 24 \mathrm{~h}$ ) at initial testing were used to subdivide diabetic subjects into those with proteinuria in the normal range and those with subclinical proteinuria. The two subgroups of diabetic subjects had similar initial and final values for fasting and 2-h plasma glucose concentrations, blood pressure, weight loss achieved and for the known duration of diabetes. As shown in Figure 2, 11 out of the 24 diabetic subjects had albuminuria in the subclinical range at baseline whereas only three out of the 24 had elevated albumin excretion following weight loss $(p<0.025)$. Similarly, for 11 out of the 24 diabetic subjects, initial protein excretion was $>60 \mathrm{mg} / 24 \mathrm{~h}$, but only four of the 24 had elevated protein excretion at final testing $(p<0.05)$. In contrast, all of the diabetic subjects $(n=13)$ with initial protein or albumin excretion in the normal range remained in the normal range.

Relationships between the changes in proteinuria and other variables were examined. The changes in $24-\mathrm{h}$ albumin excretion following therapy were correlated with the initial values of albumin excretion for all subjects as well as for the diabetic subjects alone ( $r=0.56$, $p<0.005$, Fig. 3). Similarly, the changes in 24 -h protein excretion for all subjects $(r=0.62, p<0.001)$ and for diabetic subjects alone $(r=0.57, p<0.005)$ were correlated with the initial values of protein excretion. The decreases in total protein and albumin in the diabetic patients and subjects with impaired tolerance were correlated to some extent with the decrease in 2-h plasma glucose level $(r=0.30$ for total protein and $r=0.17$ for albumin, Spearman rank correlation coefficient), but neither of these associations was statistically significant. In addition, the changes in 24-h excretion of protein or albumin for the diabetic group did not correlate with changes in body weight, fasting plasma glucose concentration, nor with changes in blood pressure. Indeed, for all subjects or for diabetic subjects alone, when stepwise regressions were performed by regressing changes in albumin excretion on changes in 2 -h plasma glucose concentrations, body weight, creatinine clearance, systolic blood pressure and on initial albumin excretion, significant associations were observed only with initial albumin excretion. 
Table 3. Urinary clearance rates of protein, albumin and creatinine

\begin{tabular}{|c|c|c|c|c|c|c|}
\hline \multirow[t]{2}{*}{ Urinary clearance } & \multicolumn{2}{|c|}{ Non-diabetic subjects } & \multicolumn{2}{|c|}{ Glucose intolerant subjects } & \multicolumn{2}{|c|}{ Diabetic patients } \\
\hline & Before diet & After diet & Before diet & After diet & Before diet & After diet \\
\hline $\begin{array}{l}\text { Protein } \\
\left(\mathrm{ml} / \mathrm{min} \times 10^{5}\right)\end{array}$ & $\begin{array}{l}22.7 \\
(5.5-47.6)\end{array}$ & $\begin{array}{l}14.2 \\
(7.1-39.3)\end{array}$ & $\begin{array}{l}59.3 \\
(14.8-146)\end{array}$ & $\begin{array}{l}39.6 \\
(14.6-66.3)\end{array}$ & $\begin{array}{l}76.9 \\
(47.4-140)\end{array}$ & $\begin{array}{l}29.2^{\mathrm{b}} \\
(21.3-49.0)\end{array}$ \\
\hline $\begin{array}{l}\text { Albumin } \\
\left(\mathrm{ml} / \mathrm{min} \times 10^{5}\right)\end{array}$ & $\begin{array}{l}13.8 \\
(6.7-20.3)\end{array}$ & $\begin{array}{l}9.7 \\
(6.5-15.7)\end{array}$ & $\begin{array}{l}45.4 \\
(5.2-114)\end{array}$ & $\begin{array}{l}24.6 \\
(6.1-71.1)\end{array}$ & $\begin{array}{l}45.0 \\
(22.6-106.7)\end{array}$ & $\begin{array}{l}19.6^{\mathrm{a}} \\
(12.7-34.2)\end{array}$ \\
\hline $\begin{array}{l}\text { Creatinine } \\
(\mathrm{ml} / \mathrm{s})\end{array}$ & $\begin{array}{l}2.0 \\
1.4-2.6\end{array}$ & $\begin{array}{l}1.7 \\
1.4-2.2\end{array}$ & $\begin{array}{l}2.7 \\
2.1-3.2\end{array}$ & $\begin{array}{l}2.6 \\
2.1-3.1\end{array}$ & $\begin{array}{l}2.3 \\
2.0-2.7\end{array}$ & $\begin{array}{l}2.0^{\mathrm{b}} \\
(1.8-2.2)\end{array}$ \\
\hline
\end{tabular}

Urinary clearance of total protein, albumin and creatinine (presented as median $+95 \%$ confidence limits) were calculated from the 24 -h urinary excretion and the plasma concentration of each substance. Significance of changes from before to after diet therapy in each group: ${ }^{a} p<$ $0.01,{ }^{\mathrm{b}} p<0.001$

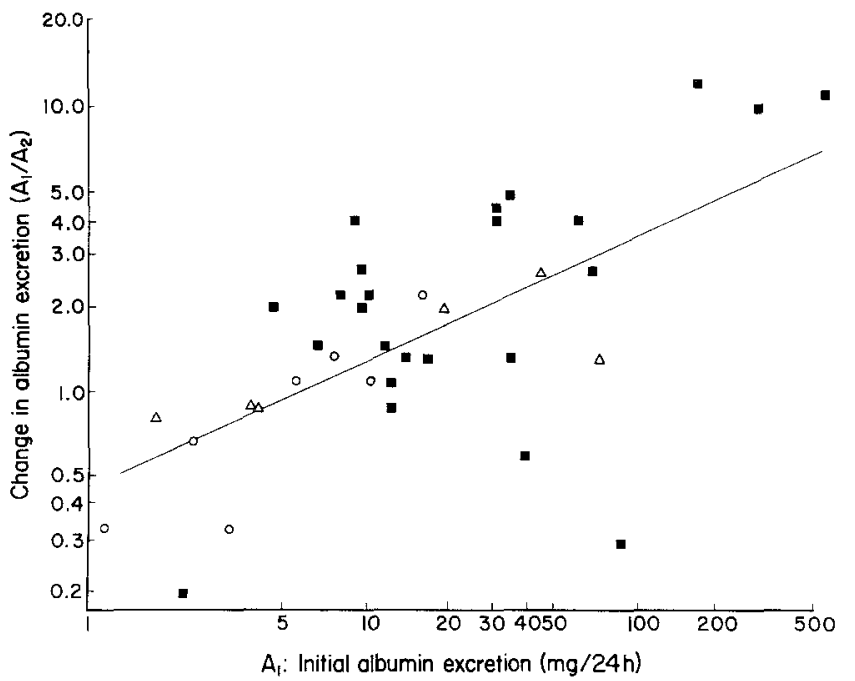

Fig.3. Relationship between initial albumin excretion and improvement in albumin excretion after weight loss. The changes in albumin excretion $(\mathrm{mg} / 24 \mathrm{~h})$ following hypocaloric diet therapy $\left(\mathrm{A}_{1} / \mathrm{A}_{2}\right)$ are plotted as a function of initial albumin excretion $\left(A_{1}\right)$ for non-diabetic control $(O)$, glucose intolerant $(\Delta)$ and diabetic $(\boldsymbol{E})$ subjects

\section{Urinary clearance of creatinine, protein and albumin}

Concentrations of plasma total protein, albumin, and creatinine during the initial and final series of tests were within normal limits in all three groups. No significant differences were found between the groups at either the initial or final tests, nor within the groups between the initial and final measurements.

Urinary clearance rates of total plasma protein and albumin (Table 3) before and after the period of weight loss remained essentially unchanged in the non-diabetic group, but declined in both the glucose intolerant and diabetic groups. The reductions in urinary clearance rates for both protein $(p<0.0001)$ and albumin $(p<$ $0.01)$ were significant in the diabetic patients. Creatinine clearance was normal in all subjects, with the highest values recorded in the subjects with impaired glucose tolerance. After diet therapy, creatinine clearance declined in all groups but changed significantly only in the diabetic group $(p<0.001)$. The possibility exists, however, that reductions in creatinine clearance may be due to reduction in dietary protein.

\section{Follow-up study}

In one diabetic patient, changes in glucose tolerance and urinary albumin excretion were followed over 14 months. Fasting glucose levels returned to normal within the first month of hypocaloric diet therapy but oral glucose tolerance was not normal until the end of the fourth month. The major reduction in proteinuria, as with fasting glucose, occurred after the initial month of diet therapy. After 6 months of caloric restriction, this subject was placed on a weight-maintaining diet (1700 $\mathrm{kcal} /$ day) for 1 month and was then discharged. When retested 8 months later, the subject had regained $14 \mathrm{~kg}$ but his glucose tolerance had decreased only slightly. Lowest levels of proteinuria were noted at the time of the final examination after glucose tolerance had been normal for approximately 10 months.

\section{Discussion}

Metabolic control of Type 2 diabetes by hypocaloric diet therapy resulted in decreases in protein excretion and clearance rate and the reduced proteinuria could be sustained for a period of several months. This study is the first demonstration that metabolic control of Type 2 diabetic subjects reduces proteinuria. These observations support the concept, proposed from studies in Type 1 diabetes, that improved control of hyperglycaemia will reverse mild to moderate increases in proteinuria and thus may decrease the rate of progression to significant renal disease $[10,20]$. The effect of diet therapy in reducing proteinuria in Type 2 diabetic patients is similar to that found in an animal model of diabetes in which dietary control of hyperglycaemia prevented nephropathy [21].

Control of hyperglycaemia in Type 1 diabetic subjects has been previously shown to decrease subclinical proteinuria [11, 12, 22]. Correction of hyperglycaemia in subjects with clinical proteinuria and Type 1 diabetes, 
however, has not be shown to arrest or reverse deteriorating renal function or albumin clearance, suggesting that renal damage may be self-sustaining and irreversible in those with more severe proteinuria [23, 24]. In the present study, we have shown that metabolic control is associated with a reduction in urinary excretion and clearance of protein and albumin in Type 2 diabetics with subclinical proteinuria, a situation analogous to that in the Type 1 diabetics with subclinical proteinuria. Whether or not clinical proteinuria in Type 2 diabetes is reversible is unknown.

The causal factors and mechanisms responsible for the development of mild to moderate proteinuria of diabetes are not completely understood. Considerable evidence exists that hyperglycaemia and/or an associated metabolic abnormality may contribute to the development of diabetic nephropathy [1-3]. Epidemiological studies demonstrate that development of retinopathy and proteinuria in Type 2 diabetic subjects is associated with elevated plasma glucose concentrations [25]. Alterations in renal haemodynamics secondary to hyperglycaemia have been postulated to play a role in the initiation and progression of diabetic glomerulopathy [26]. Glomerular filtration rate is elevated in newly diagnosed Type 1 diabetic patients and this may be associated with intrarenal hypertension. This hyperfiltration is reduced to normal or near-normal levels following reduction of blood glucose by insulin therapy [27-29]. In our study, creatinine clearance rate, a crude measure of glomerular filtration rate, was significantly reduced in Type 2 diabetic subjects following diet therapy which substantially reduced the blood glucose concentrations.

Hyperglycaemia alone, however, may not be sufficient for the development of proteinuria, since not all diabetics develop this microvascular complication of their disease [1-3]. Urinary albumin excretion is elevated in many Type 2 diabetic patients of recent onset and in diabetic subjects of long duration with retinopathy, but excretion in diabetic patients of long duration without retinopathy was not different from that of non-diabetic subjects [30]. These findings are consistent with an hypothesis that sub-populations of diabetic patients differ in their susceptibility to the microvascular complications of diabetes.

The specific metabolic changes which accompany control of diabetes and which cause the reduction in proteinuria are unknown. While reduction in plasma glucose is a common feature in the reversibility of subclinical proteinuria following diet therapy of Type 2 diabetes and insulin therapy of early Type 1 diabetes, the reductions in protein and albumin excretion observed for the diabetic group in this study were not significantly correlated with the improvements in glucose tolerance although both fell concomitantly. Blood pressure also fell concomitantly, but was not significantly correlated with the change in protein or albumin excretion. On the other hand, it is unlikely that changes in insulin concentrations are directly responsible because insulin secretion increased only modestly on average in Type 2 diabetic subjects following diet therapy [13]. Thus no specific mechanism for the reduction in proteinuria can be discerned in the present study.

Detection of mild to moderate proteinuria using accurate and sensitive immunological assays for total protein or albumin may provide a tool for identification of diabetics at risk for development of the microvascular complications of diabetes. Longitudinal studies will be required to determine whether subclinical proteinuria is predictive of the development of clinical nephropathy in Type 2 diabetes, as suggested for Type 1 diabetes [10] and clinical trials will be necessary to determine if clinical proteinuria in Type 2 diabetes is reversible. In view of the implications for selecting patients for aggressive therapy in efforts to reduce complications, more information must be obtained regarding efficacy of intervention at different stages of diabetic nephropathy.

Acknowledgements. The authors would like to thank volunteers from the Gila River Indian Community who made this study possible, Ms A. Kennedy for expert technical assistance and Ms P. J. Loco for assistance in preparation of the manuscript. We are also indebted to Ms J. Koopman and the nursing staff and Ms M. Hendrickx and the staff of the metabolic kitchen for help with the studies.

\section{References}

1. Tchobroutsky G (1978) Relation of diabetic control to development of microvascular complications. Diabetologia 15: 143-152

2. Skyler IS (1979) Complications of diabetes mellitus: relationship to metabolic dysfunction. Diabetes Care 2: 499-509

3. Brownlee M, Cahill GF (1979) Diabetic control and vascular complications. Atheroscl Rev 4: 29-70

4. Service FJ, Molnar GD, Rosevear JW, Ackerman E, Gatewood LC, Taylor WF (1970) Mean amplitude of glycemic excursions, a measure of diabetic instability. Diabetes 19: 644-655

5. Raskin P (1978) Diabetic regulation and its relationship to microangiopathy. Metabolism 27:235-252

6. Felig P, Tamborlane WV (1980) Insulin delivery devices. Ann Int Med 93:627-629

7. Knowles HC Jr. (1971) Long term juvenile diabetes treated with unmeasured diet. Trans Assoc Am Physicians 84: 95-101

8. Deckert T, Poulson JE, Larsen M (1978) Prognosis of diabetes with diabetes onset before the age of thirty-one. Diabetologia 14: 363-370

9. Knowler WC, Bennett PH, Ballintine EJ (1980) Increased incidence of retinopathy in diabetes with elevated blood pressure. New Eng J Med 302: 645-50

10. Viberti GC, Jarrett RJ, Mahmud LL, Hill RD, Argyropoulus A, Keen $H$ (1981) Microalbuminuria as a predictor of clinical nephropathy in insulin-dependent diabetes mellitus. Lancet 1: $1430-1432$

11. Parving HH, Noer I, Deckert T, Eurin PE, Nielsen SL, Lyngsoe J, Mogensen CE, Rorth M, Svendsen PA, Trap-Jensen J, Lassen NA (1976) The effect of metabolic regulation on microvascular permeability to small and large molecules in short-term juvenile diabetics. Diabetologia 12:161-166

12. Viberti GC, Pickup JC, Jarrett RJ, Keen H (1979) Effect of control of blood glucose on urinary excretion of albumin and microglobulin in insulin dependent diabetes. N Eng J Med 300: 638-641

13. Savage PJ, Bennion LJ, Flock EV, Nagulesparan M, Mott D, Roth J, Unger RH, Bennett PH (1979) Diet-induced improvement of abnormalities in insulin and glucagon secretion and in insulin re- 
ceptor binding in diabetes mellitus. J Clin Endocrinol Metab 48: 999-1007

14. Rendell M, Zarriello J, Drew HM, Dranbauer B, Wilson G, Ward J, Ross D (1981) Recovery from decompensated non-insulin dependent diabetes mellitus: studies of C-peptide secretion. Diabetes Care 4: 354-359

15. Keen H, Chlouverakis C (1963) An immunoassay for urinary albumin at low concentrations. Lancet 2:913-914

16. Killingsworth LM, Britain CE, Woodard LL (1975) Automated immunochemical method for determination of urinary protein of plasma origin. Clin Chem 21: 1465-1468

17. Savage PJ, Bennion LJ, Bennett PH (1979) Normalization of insulin and glucagon secretion in ketosis-resistant diabetes mellitus with prolonged therapy. J Clin Endocrinol Metab 49: 830-833

18. Hollander M, Wolfe D (1973) Non-parametric statistical methods. J Wiley \& Sons, New York

19. Hemmingsen I, Skaarup P (1975) The 24-hour excretion of plasma proteins in the urine of apparently health subjects. Scand J Clin Lab Invest 35: 347-353

20. Williamson JR, Kilo C (1977) Current status of capillary basement membrane disease in diabetes mellitus. Diabetes 26: 65-73

21. Lee SM, Bressler R (1981) Prevention of diabetic nephropathy by diet control in the $\mathrm{db} / \mathrm{db}$ mouse. Diabetes $30: 106-111$

22. Mogensen CE (1971) Urinary albumin excretion in early and longterm juvenile diabetes. Scan J Clin Lab Invest 28: 183-193

23. Tamborlane WV, Puklin JE, Bergman M, Verdonk C, Rudolf MC, Felig P, Genel M and Sherwin R (1982) Long-term improvement of metabolic control with the insulin pump does not reverse diabetic microangiopathy. Diabetes Care 5 (Suppl 1): 58-63

24. Viberti GC, Bilous RW, Mackintosh D, Bendiny JJ and Keen $\mathrm{H}$
(1983) Long-term correction of hyperglycaemia and progression of renal failure in insulin-dependent diabetes. $\mathrm{Br}$ Med J 286: 598-602

25. Pettitt DJ, Knowler WC, Lisse JR, Bennett PH (1980) Development of retinopathy and proteinuria in relation to plasma glucose concentrations in Pima Indians. Lancet 2: 1050-1052

26. Hostetter TH, Helmut GR, Brenner BM (1982) The case for intrarenal hypertension in the initiation and progression of diabetic and other glomerulopathies. Am J Med 72: 375-380

27. Mogensen CE (1971) Kidney function and glomerular permeability to macromolecules in early juvenile diabetes. Scand J Clin Lab Invest 28: 91-100

28. Mogensen CE (1976) Renal function changes in diabetes. Diabetes $25: 872-879$

29. Christiansen JS, Frandsem M, Parving HH (1981) The effect of intravenous insulin infusion on kidney function in insulin-dependent diabetes mellitus. Diabetologia 20: 199-204

30. Aronoff SL, Schnider S, Smeltzer J, Mackay W, Tchou P, Rushforth Miller M, Bennett PH (1981) Urinary excretion and renal clearance of specific plasma proteins in diabetes of short and long duration. Diabetes 30: 656-663

Received: 7 February 1983

and in revised form: 19 October 1983

Dr. P. H. Bennett

National Institute of Arthritis, Diabetes,

Digestive and Kidney Diseases

1550 East Indian School Road

Phoenix, Arizona 85014, USA 